\title{
Rule-Based Mamdani-Type Fuzzy Logic Approach to Estimate Compressive Strength of Lightweight Pumice Concrete
}

\author{
A. BEYCIOĞLU ${ }^{a, *}$ AND C. BAŞYIĞIT ${ }^{b}$ \\ ${ }^{a}$ Düzce University, Technology Faculty, Civil Engineering Department, Turkey \\ ${ }^{b}$ Süleyman Demirel University, Engineering Faculty, Civil Engineering Department, Turkey
}

\begin{abstract}
In this study, a rule-based Mamdani-type fuzzy logic (RBMFL) model was developed for prediction of compressive strength of lightweight concretes containing silica fume (SF) and fly ash (FA). Pumice was used as the aggregate in the concretes. In the concrete mixture $0,5,10,15$ and $20 \%$ of fly ash and $0,5,10,15$ and $20 \%$ of silica fume, for each value of fly ash content, were added by replacing the cement. The compressive strength of the lightweight concretes was investigated experimentally. Experimental results were used to construct the fuzzy logic model. In the study, the values obtained from the model and experiment were divided into five groups (each group has five experimental results), according to the FA and SF contents, to evaluate approximate reasoning ability of RBMFL model. As a result, RBMFL model has shown satisfying relation with experimental results, which suggests an alternative approach to evaluation of compressive strength of lightweight concretes containing silica fume and fly ash.
\end{abstract}

DOI: 10.12693/APhysPolA.128.B-424

PACS: 07.05.Mh, 02.60.- $\mathrm{x}$

\section{Introduction}

Concrete, which is widely used in the area of construction, is a relatively inexpensive material. It can be easily handled and cast into complex shapes. Concrete has an important place among materials that form the basis of modern societies. In our environment, buildings, roads, bridges, dams, power plants, retaining walls, water tanks, ports, airports, etc. are made of concrete [1-3]. The advantages of light weight concrete over the normal weight concrete are numerous and well known, e.g. lower density, higher strength/weight ratio, lower coefficient of thermal conductivity, better fire resistance, improved durability properties, etc. [4-5]. Nowadays, there is a fast development of the industry. Thus the industrial waste management policies such as recycling of wastes, using waste as new raw material, etc. become very important. In the civil engineering, the use of waste materials, partial or total, instead of conventional materials, has increased due to the economical and environmental reasons [6]. In view of the global sustainable development, it is imperative that supplementary cementing materials be used in place of cement in the concrete industry. The most worldwide available supplementary cementing materials are silica fume (SF), a by-product of silicon industry, the fly ash (FA), a by-product of thermal power stations, and granulated blast-furnace slag (GGBS), a byproduct of steel mill. Supplementary cementing materials such as FA, GGBS and SF are widely used in concrete to improve the workability and strength, or to reduce the costs [7-8]. Several studies have been carried out using various methods, to investigate some physical

*corresponding author; e-mail: abeycioglu@duzce.edu.tr and mechanical properties of concrete. Recently, artificial intelligence has been extensively used in the fields of civil engineering applications, such as construction management, building materials, hydraulic, geotechnical and transportation engineering, etc. One of the most popular artificial intelligence methods is fuzzy logic (FL). There are many studies available in the literature [9-26], aimed on estimating different concrete properties using fuzzy logic. In this study, a new fuzzy model, based on the Mamdani algorithm was introduced for prediction of compressive strength of lightweight pumice concretes, by using the fuzzy logic toolbox in MATLAB.

\section{Details of developed RBMFL model}

In this study, a new RBMFL model was introduced for prediction of compressive strength of lightweight pumice concrete by using the fuzzy logic toolbox in MATLAB. In the study SF content, FA content and cement content were used as input parameters and the compressive strength was considered as the output. RBMFL was chosen because it is based on natural language, is flexible, and is conceptually easy to understand [28]. In the RBMFL model, the input and output variables were fuzzified by choosing a triangular membership functions (trimf). The membership functions of input and output parameters are shown in the Fig. 1 and details are given in Table I. In the figures "fa" represents fly ash, "sf" represents silica fume, "cem" represents cement and "cs" represents compressive strength. After determining the input and output parameters, a total of 225 rules were developed, using the experimental data sets and experiences.

The centroid defuzzification technique was used in order to determine crisp values of outputs for this study. As the final stage, after creating the model, the results were obtained from the defuzzification monitor of the model. 


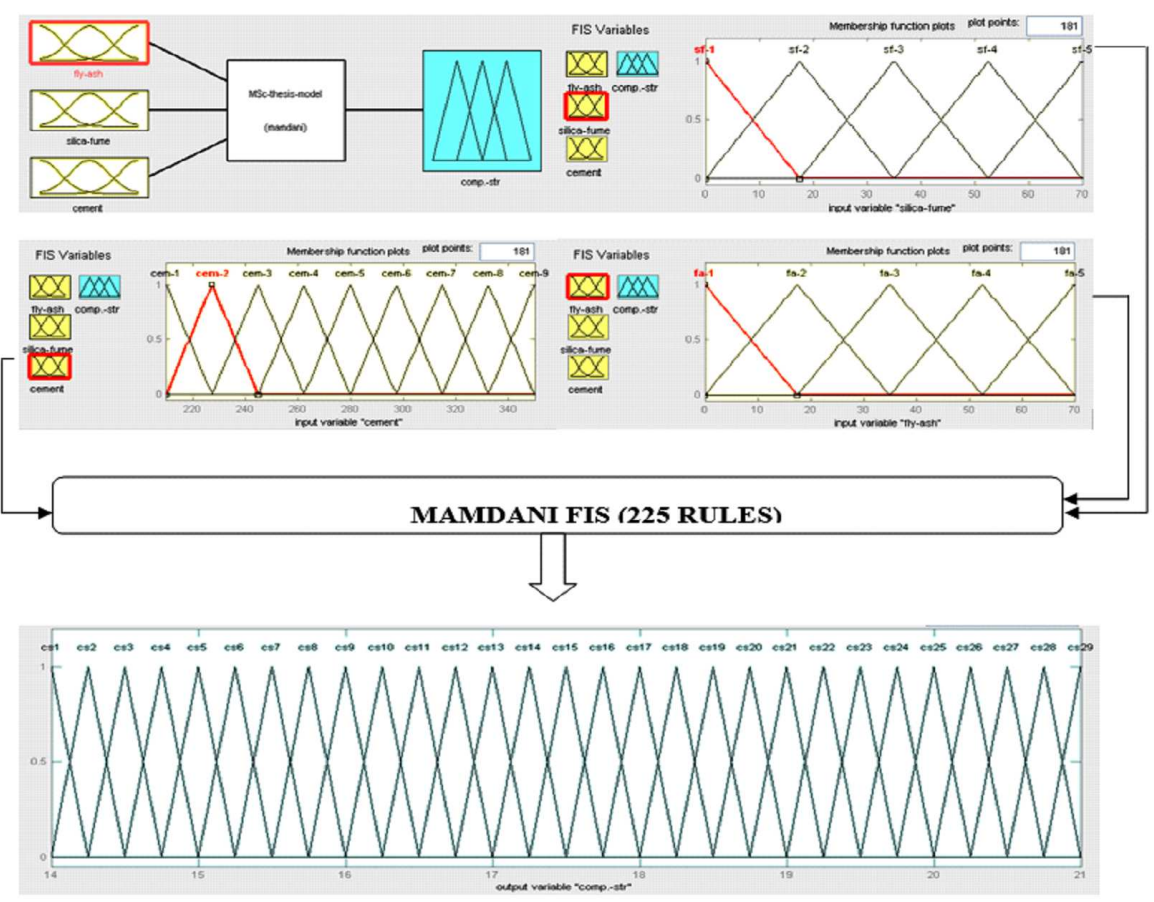

Fig. 1. Membership functions of inputs and outputs of the model.

\section{Results and discussion}

The values obtained from the model and the experiment were divided into five groups, to evaluate RBMFL model predictability. The adequacy of the developed RBMFL model was evaluated by considering three statistical evaluation criteria. These statistical parameters are the coefficient of determination $R^{2}$, the root mean square error (RMSE) and the mean absolute error (MAE). The statistical values of $R^{2}$, RMSE and MAE, for all data sets, are given in Table II.

\section{Conclusions}

According to the results, the following conclusions can be drawn:

- When the results are compared using values of the coefficient of determination $\left(R^{2}\right)$, the values were found to be 0.99 for sets I-IV and 0.98 for set V. These results show very acceptable relations between the results of the developed model and the experimental results.

- When the results are compared using the rootmean-square error (RMSE), the values were found to be 1.17 for set I, 1.18 for set II, 1.37 for set III, 1.35 for set IV and 1.59 for set V. These results show very acceptable relations between the results of the developed model and the experimental results.
TABLE I

Membership functions details of the model parameters.

\begin{tabular}{l|l}
\hline \hline \multicolumn{1}{c|}{ Parameters } & $\begin{array}{c}\text { Membership functions } \\
\text { details }\end{array}$ \\
\hline $\begin{array}{l}\text { Input - cement }\left[\mathrm{kg} / \mathrm{m}^{3}\right] \\
\text { Input - fly ash }\left[\mathrm{kg} / \mathrm{m}^{3}\right]\end{array}$ & 9 trimf, range $210-350$ \\
$\begin{array}{l}\text { Input - silica fume }\left[\mathrm{kg} / \mathrm{m}^{3}\right] \\
\begin{array}{l}\text { Output - compressive strength } \\
\text { of concrete samples (CS) }[\mathrm{MPa}]\end{array}\end{array}$ & 5 trimf, range $0-70$ \\
\hline
\end{tabular}

TABLE II

Statistics of CS and EM estimation using FL.

\begin{tabular}{c|c|c|c}
\hline \multirow{2}{*}{ Set } & \multicolumn{3}{|c}{$\begin{array}{c}\text { Statistical parameters for } \\
\text { comparison of EXP and FL }\end{array}$} \\
\cline { 2 - 4 } & $R^{2}$ & RMSE & MAE \\
\hline I FA 0\%, SF variable & 0.99 & 1.17 & 0.89 \\
II FA 5\%, SF variable & 0.99 & 1.18 & 1.03 \\
III FA 10\%, SF variable & 0.99 & 1.37 & 1.19 \\
IV FA 15\%, SF variable & 0.99 & 1.35 & 1.12 \\
V FA 20\%, SF variable & 0.98 & 1.59 & 1.39
\end{tabular}

- When the results are compared using values of the mean absolute error (MAE), the values were found to be $0.89,1.03,1.19,1.12$ and 1.39 for sets I, II, III, IV and V, respectively. These results also show very acceptable relations between model results and experimental results. 
As a result, compressive strength values of lightweight pumice concrete can be predicted for different proportions of a mix of the SF, FA and cement, using RBMFL model without attempting any experiments. This leads us to understanding that the RBMFL approach, which consideres the relation between silica fume, fly ash, cement content and the compressive strength, is an alternative way to estimate properties of the concrete, like the compressive strength. From this point, it will be possible to use this method in other materials for the purposes of the estimation of different properties.

\section{References}

[1] O. Gencel, W. Brostow, C. Ozel, M. Filiz Mater. Sci.-Medzg. 16, 249 (2010).

[2] H. Bınıci, M.Y. Durgun, T. Rızaoğlu, M. Koluçolak, Sci. Iran. 19, 366 (2012).

[3] M.J. Shannag, Constr. Build. Mater. 25, 658 (2011).

[4] N.A. Libre, M. Shekarchi, M. Mahoutian, P. Soroushian, Constr. Build. Mater. 25, 2458 (2011).

[5] F. Koksal, O. Gencel, H.E.H. Lobland, W. Brostow, Mater. Res. Innov. 16, 7 (2012).

[6] A. Beycioglu, Modeling the effects of industrial wastes on properties of lightweight concrete by fuzzy logic method, Graduate School of Applied and Natural Science, Süleyman Demirel University, 2008.

[7] Z. Shui, R. Zhang, W. Chen, D. Xuan, Constr. Build. Mater. 24, 1761 (2010).

[8] V.M. Malhotra, P.K. Mehta, High Performance, High Volume Fly Ash Concrete Supplementary Cementing Materials for Sustainable Development, Ottawa 2002.

[9] E.M. Golafshani, A. Rahai, M.H. Sebt, H. Akbarpour, Constr. Build. Mater. 36, 411 (2012).

[10] A. Nazari, Ceram. Int. 38, 4729 (2012).
[11] M.-Y. Cheng, J.-S. Chou, A.F.V. Roy, Y.-W. Wu, Aut. Constr. 28, 106 (2012).

[12] Z.H. Duan, S.C. Kou, C.S. Poon, Constr. Build. Mater. 36, 947 (2012).

[13] Behrouz Ahmadi-Nedushan, Constr. Build. Mater. 36, 665 (2012).

[14] F. Demir, Cement Concrete Res. 35, 1531 (2005).

[15] F. Özcan, C.D. Atiş, O. Karahan, E. Uncuoğlu, H. Tanyildizi, Adv. Eng. Softw. 40, 856 (2009).

[16] A. Khanfar, M. Abu-Khousa, N. Qaddoumi, Compos. Struct. 62, 335 (2003).

[17] İ.B. Topçu, M. Sarıdemir, Constr. Build. Mater. 22 , 532 (2008).

[18] O. Ünal, F. Demir, T. Uygunoğlu, Build. Environ. 42, 3589 (2007).

[19] H. Tanyildizi, Adv. Eng. Softw. 40, 161 (2009).

[20] K. Güler, F. Demir, F. Pakdamar Constr. Build. Mater. 37, 680 (2012).

[21] M. Sarıdemir, İ.B. Topçu, F. Özcan, M.H. Severcan Constr. Build. Mater. 23, 1279 (2009).

[22] F. Köksal, Y. Şahin, A. Beycioğlu, O. Gençel, W. Brostow, Sci. Eng. Compos. Mater. 19, 373 (2012).

[23] S. Subaşı, A. Beycioğlu, E. Sancak, İ. Şahin, Neural Comput. Appl. 22, 1133 (2013).

[24] H. Tanyildizi Mater. Design 30, 2205 (2009).

[25] I. Akkurt, C. Başyigit, S. Kilincarslan, A. Beycioglu J. Franklin I. 347, 1589 (2010).

[26] F. Demir, K. Armagan Korkmaz, Constr. Build. Mater. 22, 1385 (2008).

[27] A. Abraham, Rule Based Expert Systems, Handbook for Measurement Systems Design, Eds. P. Sydenham, R. Thorn, John Wiley and Sons, London 2005, p. 909.

[28] MATLAB Fuzzy Logic Toolbox ${ }^{\text {TM }}$, User's Guide R2011b. 